\title{
ENVIRONMENTAL IMPACT ASSESSMENT THROUGH GREENHOUSE GAS ACCOUNTING OF ELECTRICITY CONSUMED BY THE ALUMINUM PLANT PODGORICA (KAP) FOR THE PERIOD 2003-2016
}

Selim Lika

Founder, Center for Economic, Environmental and Sustainable Research of the Balkans, Podgorica, Montenegro

\begin{abstract}
:
Over the last half century, the Aluminum Plant Podgorica has been the largest energy consumer in Montenegro. That is mainly because the entire process of transforming raw bauxite into aluminum is incredibly energy intensive, requiring copious amounts of electricity, water and resources. Since pure aluminum ore is so stable, an extraordinary amount of electricity is required to yield the final product, and usually more than half of the smelting energy consumed is the courtesy of coal, being one of the most notoriously polluting fuel sources known to mankind. Such environmental impact of the plant is huge, making its mere existence questionable from both the financial and environmental point of view.
\end{abstract}

Keywors:

greenhouse gas, accounting, environment, Aluminum plant, energy.

\section{INTRODUCTION}

Securing a reliable, economically viable and environmentally sound energy supply is and will continue to be a major challenge for all the companies operating in the Balkans, including Montenegro. Having in mind strong coal dependency in terms of energy production, it is very hard to prepare for future emission reduction challenges set by the European Union (Ministarstvo ekonomije Crne Gore, 2015). In order to be in line with the EU emission reduction targets by 2020 and afterwards, a set of deep reforms and changes is planned at the governmental level that will directly impact large energy consumers.

Over the past half century, Aluminum Plant Podgorica has been the largest energy consumer in Montenegro. That is mainly due to the fact that the entire process of transforming raw bauxite into aluminum is incredibly energy intensive, requiring copious amounts of electricity, water and resources. Since pure aluminum ore is so stable, an extraordinary amount of electricity is required to yield the final product and more than half of the smelting energy consumed is attributed to coal, as one of the most notoriously polluting fuel sources known to mankind (Elizah Leigh, 2010). Such environmental impact of the plant is huge, thus making its mere existence questionable from both the financial and environmental point of view.

The problem of emissions is becoming a current issue in all serious companies, and developing the appropriate risk management strategy is deemed necessary. In sectors that are heavy emitters, greening the supply chain is the only viable option. Some companies in the aluminum industry have already started using top-down mandates to incorporate sustainability into each business unit's practices. This was done upon a thorough analysis of real operating costs that included the monetary value of environmental impacts of the company. 
The principal idea of this research is to analyze the energy consumption of the Aluminum plant in Montenegro (KAP) and give a monetary value to the greenhouse emissions released by this consumption for the period from 2003 until 2016 (Ministarstvo ekonomije Crne Gore, 2016). The data received by this study provide an operational risk analysis for the decision makers with a clear picture of the real operating costs of the Aluminum plant in Montenegro.

In order to provide the methodological consistency, the 2006 Intergovernmental Panel on Climate Change (IPCC) Guidelines for National Greenhouse Gas Inventories was used throughout the text to complete the calculations for Montenegro. The 2006 guidelines are an update of the 1996 IPCC guidelines and provide an internationally agreed methodology for greenhouse gas estimation and reporting.

The global warming coefficients defined in the Second Assessment Report done by IPCC in 1990 were used to calculate the greenhouse gas values. For the purpose of the study, the emphasis will be solely on the values of carbon dioxide, methane and nitrous oxide. The calculated data will be equal to carbon dioxide equivalent values in order to give easier monetary value to the emissions.

The raw data were collected from government institutions in charge of or reporting on electricity and fuel consumption, international organizations and NGO's working in this field in Montenegro, as well as available publications on this topic.

The analysis was not only done from the environmental point of view, but also from the risk management point of view. Namely, we live in an ever-changing world, where a new legislation on emission reduction or a newly imposed carbon tax might make our operational model inefficient to successfully comply with it and remain profitable.
As previously explained, the focus of the analysis is on the electricity usage by the Aluminum plant in Montenegro for the period from 2003 until 2016. Those data will be used to calculate the related emissions and their potential cost. The data were taken from the yearly reports published by the Ministry of Economics on energy consumption. The reports for the given period were combined to get the continuum and data clarity.

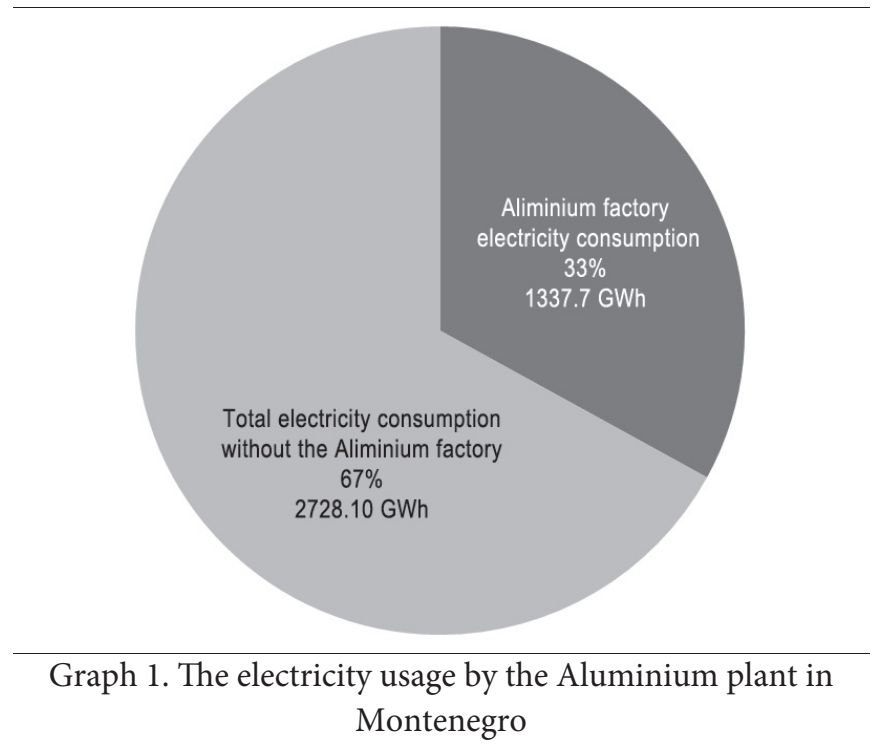

Source: Author's calculations based on the official data published in the yearly energy reports of the Ministry of Economics of Montenegro

When it comes to energy consumption in Montenegro in the observed period, the average yearly consumption was $4066 \mathrm{GWh}$. This amount accounted for direct and distributive consumption as well as for the transmission losses. Out of the total electricity consumption, on average, some 1338 GWh go directly to the Aluminum factory. This accounts for

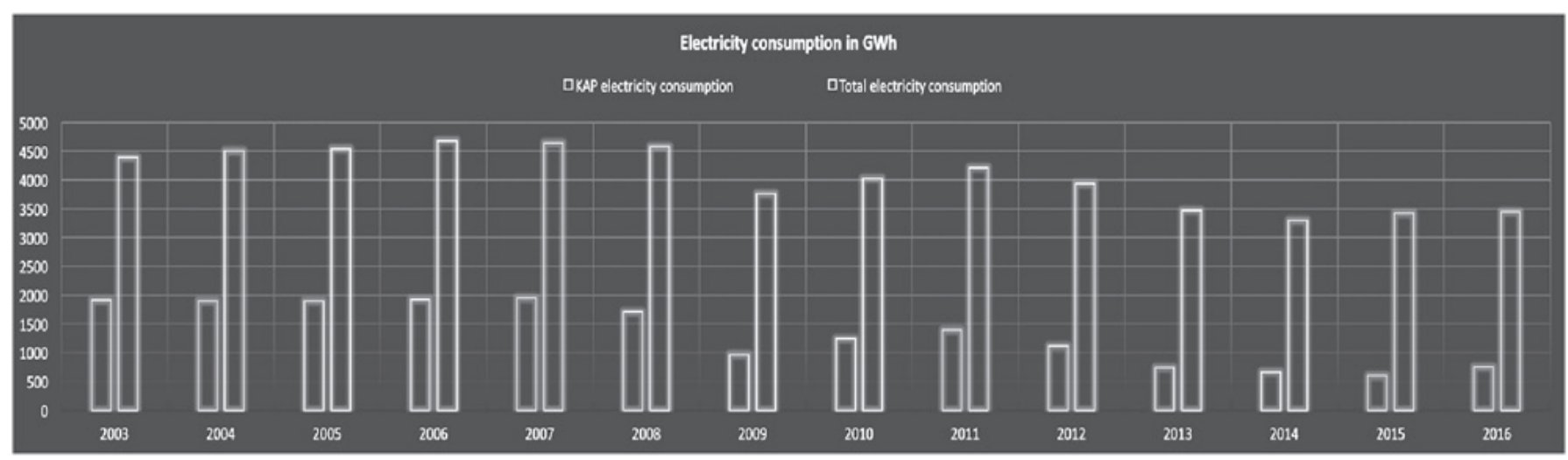

Graph 2. Electricity consumption in Montenegro (in GWh) 
more than $33 \%$ of total electricity consumption in Montenegro. Having in mind the large share of consumption, any change in either energy prices or environmental legislation aiming to reduce emissions, would severely affect the Aluminum plant, as the largest consumer.

As can be seen in the graph, its electricity consumption fluctuates on a yearly basis. The analyzed period shows a decline in energy consumption from 2007 due to the global crisis and lower aluminum prices on the market. The share for the first half of the analyzed period was above $40 \%$ of the total electricity consumption. The share in the second half of the analyzed period is much lower, but it is expected that with the economic improvements, the production will record more favourable figures.

After having a clear picture of the yearly electricity consumption of the Aluminum plant, we can use the data to calculate the values in Joules. By transferring the watt values to the derived unit of energy using the global warming coefficients, we have all mathematical variables to calculate the emissions directly related to electricity consumption.
As shown in the above-given table and graph, (Ministarstvo ekonomije Crne Gore, 2016), the carbon dioxide, methane and nitrous oxide were calculated. Other greenhouse gasses are irrelevant when it comes to electricity consumption and they do not reflect a significant difference in terms of final results. Using the second assessment report, the values of methane and nitrous oxide were transferred into carbon dioxide equivalent values, making with already calculated carbon dioxide emissions the total emissions from the electricity usage of the plant.

According to the calculations, the average yearly emissions equaled to $244.709,1$ tons of carbon dioxide equivalent. In 2003, the emissions were at their peak, equaling an amount of 373.700,6 tons of carbon dioxide equivalent, while in 2015, the emissions hit their low, accounting for only $96.113,4$ carbon dioxide equivalent. One might observe from the data that there was a mitigation strategy in place that had the goal to reduce the emissions, but if we look closer at the electricity used by the factory, we will see that the reductions are the result of bad economy for the aluminum industry

Table 1 and Graph 3. Aluminum factory electricity consumption in tones of CO2

\begin{tabular}{|c|c|c|c|c|c|c|c|c|c|c|c|c|c|c|c|}
\hline & 2003 & 2004 & 2005 & 2006 & 2007 & 2008 & 2009 & 2010 & 2011 & 2012 & 2013 & 2014 & 2015 & $2016 \mathrm{p}$ & Average \\
\hline Aluminium factory electricity consumption & 1904 & 1898 & 1897 & 1927 & 1950 & 1705 & 966 & 1241 & 1387 & 1111 & 735 & 663 & 598 & 746 & 1338 \\
\hline Conversion to TJ & 6854 & 6833 & 6829 & 6936 & 7021 & 6139 & 3477 & 4468 & 4993 & 4000 & 2646 & 2387 & 2153 & 2686 & 4816 \\
\hline iCO2 emissions & 371790.5 & 293292.3 & 323504.5 & 369025.5 & 364746.7 & 333154.6 & 143928.8 & 208472.4 & 323142.9 & 231381.2 & 139801.0 & 98015.9 & 95622.2 & 112538.9 & 243458.4 \\
\hline${ }_{1} \mathrm{CH} 4$ emissions & 3.930 & 3.100 & 3.420 & 3.901 & 3.856 & 3.522 & 1.521 & 2.204 & 3.416 & 2.446 & 1.478 & 1.036 & 1.011 & 1.190 & 2.574 \\
\hline tCOzeemissions & 373700.6 & 294799.0 & 325166.5 & 370921.4 & 366620.5 & 334866.2 & 144668.3 & 209543.4 & 324803.1 & 232569.9 & 140519.2 & 98519.4 & 96113.4 & 113117.1 & 244709.1 \\
\hline
\end{tabular}

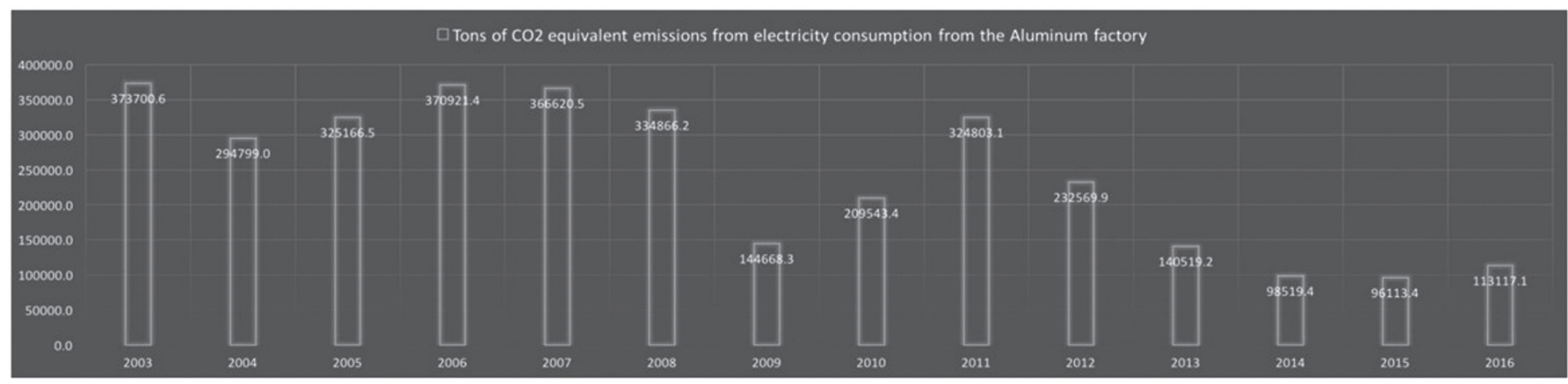

Source: Author's calculations based on the official data published in the yearly energy reports from of the Ministry of Economics of Montenegro

Table 2 and Graph 4. Environmental costs related to greenhouse gas emission from the Aluminum plant

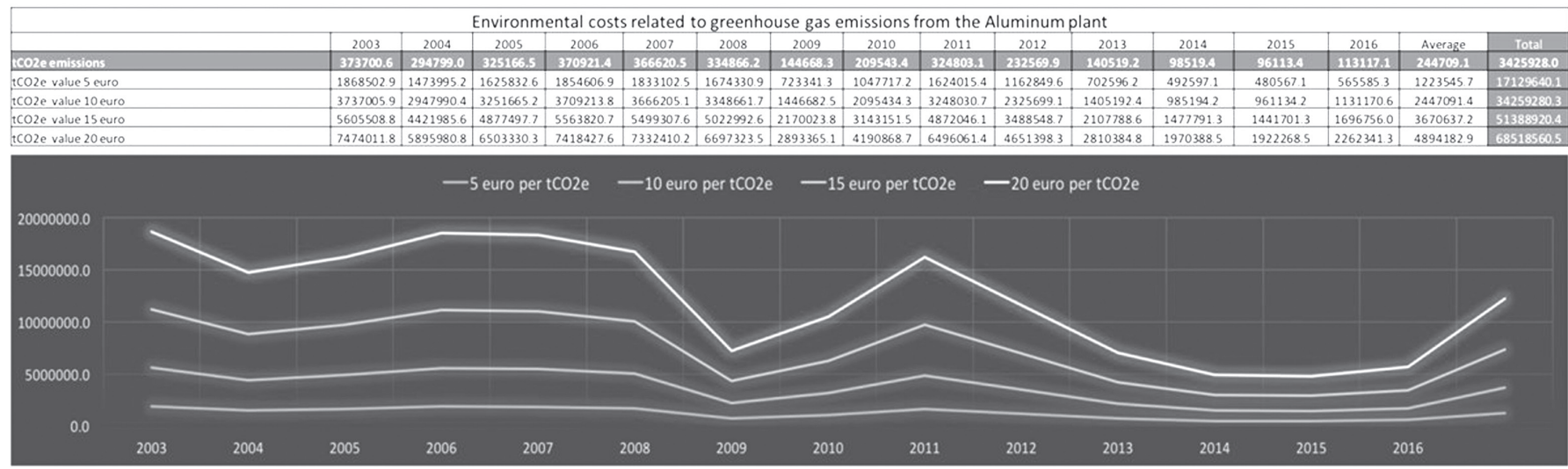

Source: Author's calculations based on the official data published in the yearly energy reports from of the Ministry of Economics of Montenegro 
and irreversible impacts that the factory suffered due to the economic crisis.

In order to calculate the real monetary value of the environmental impact from the electricity consumption of the plant, different values for one tonne of carbon dioxide equivalent were used. Having in mind the prices on the global carbon markets, values from 5 to 20 EUR per ton of carbon dioxide equivalent were calculated. The table below shows the results for different scenarios.

According to the calculations, the total environmental cost on the lowest scenario (5 euro per tonne of CO2e) for the given period was 17.13 million euro, or on average, some 1.22 million euro per year. The 20 euro per ton scenario resulted in the total environmental cost of 68.5 million euro, or an average of 4.89 million euro per year.

The costs are only related to electricity consumption of the aluminum plant and not to other production related emissions. There is a lack of data that would allow calculating the total emissions from the aluminum plant, since there is no study that covers the given period. Still, the data from the Second National Communication (Ministry of Sustainable Development and Tourism, 2015) provide information on emissions until 2011.

The process of primary aluminum production is done by the electrolytic reduction of the alumina. The alumina is dis- solved in a molten bath of fluoride compounds (the electrolyte) and an electric current is passed through the bath which causes the alumina to dissociate to form liquid aluminum and oxygen which reacts with carbon in the electrode to produce carbon dioxide and carbon monoxide (IPCC, 2006). The production process also releases tetraflouromethane (CF4) and hexaflouroethane (C2F6) gases, with a very high global warming potential (IPCC, 2006). When we transform all the greenhouse gases released from the aluminum plant into carbon dioxide equivalent emissions, we get the alarming data. Namely, in 2007 when the emissions peaked, the amount of emissions equaled to 1.790 .220 tons of carbon dioxide only from the aluminum plant. On average, the emissions equaled to 1.320.421 tons of carbon dioxide for the given period (Ministry of Sustainable Development and Tourism, 2015).

Having calculated all the emissions related to the plant's operations, we can now assign a monetary value to them. The same approach and scenario for one ton of carbon dioxide equivalent used with the electricity consumption was used herein as well. The data show that the average yearly environmental cost under the 5 EUR per ton of carbon dioxide equivalent equaled to 6.6 million EUR. Under the higher end scenario of 20 EUR, the average yearly environmental cost equaled to 26.4 million EUR.

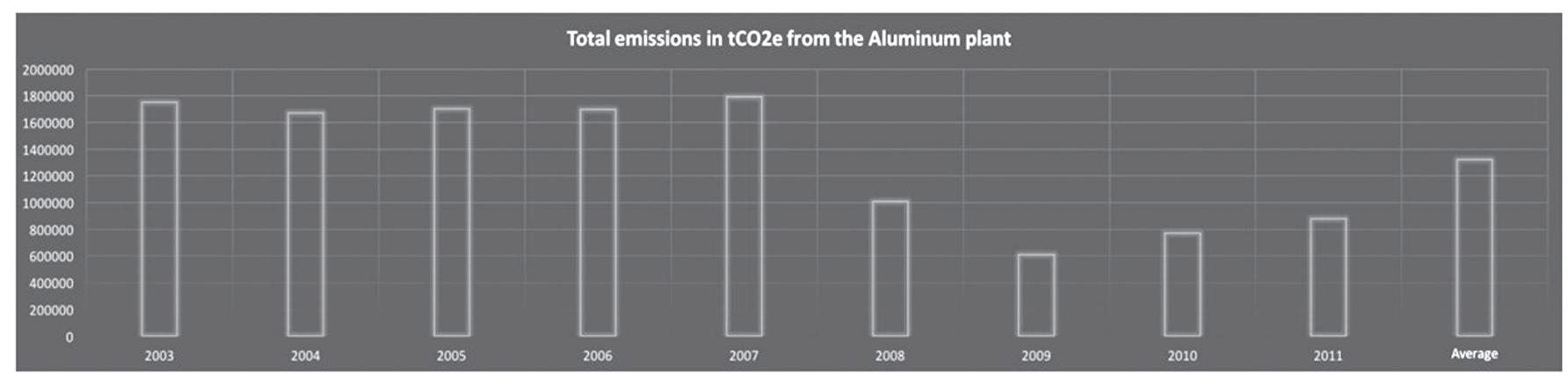

Graph 5. Total emission in $\mathrm{CO}_{2}$ from the Aluminum plant

Source: Author's calculations based on the official data published in the yearly energy reports of the Ministry of Economics of Montenegro

Table 3 and Graph 6. Monetary value of emissions related to Aluminum plant

\begin{tabular}{|c|c|c|c|c|c|c|c|c|c|c|c|}
\hline & 2003 & 2004 & 2005 & 2006 & 2007 & 2008 & 2009 & 2010 & 2011 & Average & Total \\
\hline tCO2e emissions & 1751701 & 1672799 & 1703167 & 1697621 & 1790221 & 1006765 & 611368 & 773143 & 877003 & 1320421 & 11883789 \\
\hline tCO2e value 5 euro & 8758503 & 8363995 & 8515833 & 8488107 & 8951103 & 5033831 & 3056841 & 3865717 & 4385015 & 6602105 & 59418945 \\
\hline tCO2e value 10 euro & 17517006 & 16727990 & 17031665 & 16976214 & 17902205 & 10067662 & 6113683 & 7731434 & 8770031 & 13204210 & 118837890 \\
\hline tco2e value 15 euro & 26275509 & 25091986 & 25547498 & 25464321 & 26853308 & 15101493 & 9170524 & 11597151 & 13155046 & 19806315 & 178256834 \\
\hline tCO2e value 20 euro & 35034012 & 33455981 & 34063330 & 33952428 & 35804410 & 20135323 & 12227365 & 15462869 & 17540061 & 26408420 & 237675779 \\
\hline
\end{tabular}

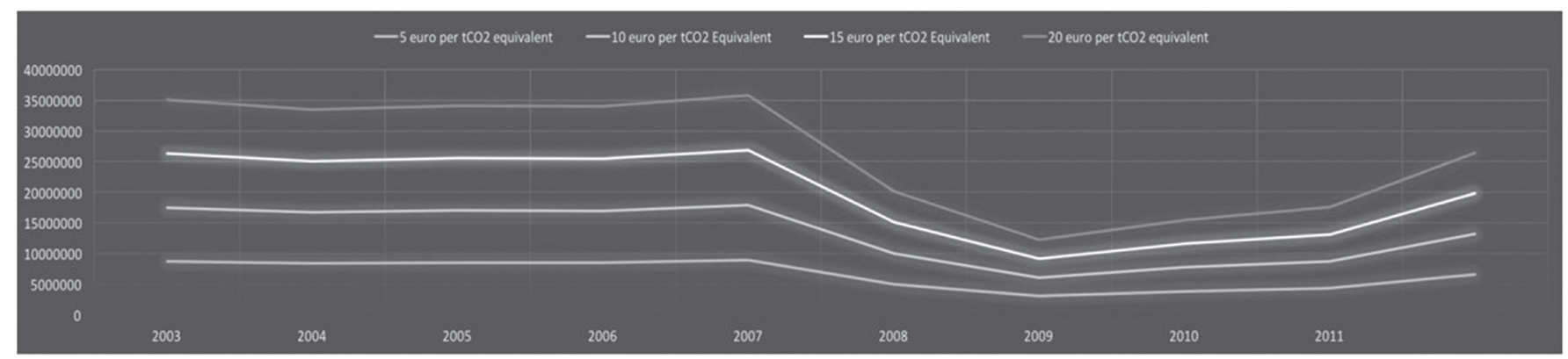

Source: Author's calculations based on the official data published in the yearly energy reports of the Ministry of Economics of Montenegro 
The above-given table and graph provide a detailed analysis of emissions on a yearly basis as well as their trends. With such high environmental costs, the operational model becomes unsustainable and requires a major change to become sustainable.

\section{CONCLUSION}

In case of the Aluminum plant in Montenegro, inevitable advances in climate legislation pose huge risks for this emission-intensive industry. Under the proposed European Union guidelines, the mere existence of the plant becomes questionable. The risks linked to the emissions from electricity consumption could be mitigated by purchasing power from renewable energy sources. This would result in somewhat higher electricity prices, but would make up in company image, public support as well as lower number of financial restrictions imposed by the government due to the pollution.

Recent studies indicate that citizens and consumers support private sector leadership on climate change mitigation (Tara O'Shea, 2013). The main problem with such risk management strategy would be how to mitigate the emissions deriving from the aluminum production itself. Here, the technology plays a major role. Having in mind that the Aluminum plant in Montenegro uses the technology that is over 40 years old, it is hardly possible to bring the emission levels in line with the European Union standards. The calculations of average yearly emissions shown herein suggest that the Government of Montenegro should seriously consider shutting down this plant. The electricity saved could be sold on the market and if we add the possibility of selling carbon credits to the European Union countries in the amount of the current emissions, it would make more sense financially than keep the plant running.

\section{LITERATURE}

Archer, D., \& Rahmstorf, S. (2010). The Climate Crisis: An Introductory Guide to Climate Change. Cambridge University Press.

Bayon, R., Hawn, A., \& Hamilton, K. (2009). Voluntary Carbon Markets: An International Business Guide to What They Are and How They Work. London: Routledge.

Bode, S. (2004). Equal Emissions per Capita over Time - A Proposal to Combine Responsibility and Equity of Rights for Post-2012 GHG Emission Entitlement Allocation. European Environment, Volume 14.

Bowen, M. (2006). Thin Ice: Unlocking the Secrets of Climate in the World's Highest Mountains. Holt Paperbacks.

Brohe, A., Eyre, N., Howarth, N., \& Stern, N. (2009) Carbon Markets: An International Business Guide (Environmental Market Insights). London: Routledge.
Business Europe. (2010). Climate and Energy: Position Paper, 2010. Available on http://www.businesseurope.eu/content/default.asp?PageID=568\&DocID=27287

Business Europe. (2011). European Business Recommendations on EU Policies for Census of Population, Households and Dwellings in Montenegro 2011.

Climate Action Network Europe (2010). Horizont 2050. Steel, Cement \& Paper. Identifying the breakthrough technologies that will lead to dramatic greenhouse gas reductions by 2050. Available on http://www.climnet.org/component/docman/ doc_download/1716-steel-paper-and-cement-identifyingbreakthrough-technologies-oct 2010

Climate strategies (2012). Strengthening the EU ETS creating a stable platform for EU energy sector investment. Available on http://www.climatestrategies.org/research/our-reports/ category/60/343.html

COGEN Europe (2010). Cogeneration as the foundation of Europe's 2050 low carbon energy policy: Report, 2010. Available on http://www.cogeneurope.eu/wp-content/ uploads//2010/12/011210-COGEN-Europe-report- Cogeneration-as-the-foundation-of-Europe-s-2050-low-carbonenergy-policy.pdf

Eurelectric (2010). Power Choices: Pathways to carbon-neutral electricity in Europe by 2050: Full report 2010. Available on http://www.eurelectric.org/Download/Download. aspx? DocumentFileID $=63875$

European Climate Foundation (2010). Roadmap 2050: A practical guide to a prosperous, low-carbon Europe: Technical analysis, 2010. Available on http://www.europeanclimate. org/index.php?option=com_content\&task=view\&id=72\& Itemid $=79$

European Commission (2011.) EU low carbon roadmap: A roadmap for moving to a competitive low carbon economy in 2050. Available on http://eur-lex.europa.eu/LexUriServ/ LexUriServ.do?uri=COM:2011:0112:FIN:EN:PDF

European Renewable Energy Council (2010). Re-thinking 2050. A 100\% Renewable Energy Vision for the European Union: Executive Summary, 2010. Available on http://www.rethinking2050.eu/

Federal Ministry of Economics and Technology (2008). Energy Concept for an Environmentally Sound, Reliable and Affordable Energy Supply. Available on http://www.bmu.de/ files/english/pdf/application/pdf/energiekonzept_bundesregierung_en.pdf

Galharret, S., \& Guerin, E. (2011). The EU Climate and Energy Package: Elements to assess its current performance and suggestions on the way forward. Available on http://www. iddri.org/Publications/Collections/Idees-pour-le-debat/ ID_1101_galharret\%20guerin $\% 20 \mathrm{eu} \% 20$ climate $\% 20$ energy\%20package.pdf

Hanley N., Shogren J. F. \& White B. (2001). Introduction to Environmental Economics. Oxford: Oxford University Press.

Harris, M. J. (2009). Ekonomija životne sredine i prirodnih resursa: savremeni pristup. Beograd: Data status.

Ministarstvo ekonomije (2010). Akcioni plan energetske efikasnosti. Available on http://www.energy-community.org/ pls/portal/docs/986180.PDF 
Ministarstvo ekonomije (2011). Energetski balans Crne Gore za 2011. godinu. Available on http://www.epcg.co.me/pdf/01_03_02/ energetski_bilans_2011.pdf

Ministarstvo ekonomije (2012). Energetski balans Crne Gore za 2012. godinu. Available on http://www.epcg.co.me/pdf/01_03_02/ energetski\%20bilans\%202012.pdf

Ministarstvo ekonomije (2013). Energetski balans Crne Gore za 2013. godinu. Available on http://www.epcg.co.me/ pdf/01_03_02/energetski\%20bilans\%202013.pdf

Ministarstvo ekonomije (2014). Energetski balans Crne Gore za 2014. godinu. Available on http://www.admin.epcg. com/sites/admin.epcg.com/files/multimedia/main_pages/ files/2013/08/energetski_bilans_crne_gore_za_2014._godinu.pdf\#overlay-context=o-nama/proizvodnja-i-elektroenergetski-bilans

Ministarstvo ekonomije (2015). Energetski balans Crne Gore za 2015. godinu. Available on http://www.admin.epcg. com/sites/admin.epcg.com/files/multimedia/main_pages/ files/2013/08/energetski_bilans_crne_gore_za_2015._godinu.pdf\#overlay-context=o-nama/proizvodnja-i-elektroenergetski-bilans

Ministarstvo ekonomije (2016). Energetski balans Crne Gore za 2016. godinu. Available on http://www.epcg.com/sites/admin. epcg.com/files/multimedia/Energetski_bilans/energetski_bilans_2016.pdf

Ministarstvo ekonomskog razvoja (2007). Strategija razvoja sektora energetike Crne Gore do 2025. godine. Available on http://www.mek.gov.me/files/1202471750.pdf

World Business Council for Sustainable Development (2010). Vision 2050: The new agenda for business. Available on http://www.wbcsd.org/web/projects/BZrole/Vision2050FullReport_Final.pdf

World Resources Institute (2012). GHG mitigation in the EU: An overview of the current policy landscape. Available on http:// pdf.wri.org/ghg_mitigation_eu_policy_landscape.pdf

\section{ISPITIVANJE UTICAJA EMISIJA GASOVA SA EFEKTOM STAKLENE BAŠTE NA ŽIVOTNU SREDINU USLED POTROŠNJE ELEKTRIČNE ENERGIJE U KOMBINATU ALUMINIJUMA PODGORICA (KAP) U PERIODU OD 2003. DO 2016. GODINE}

\begin{abstract}
Apstrakt:
U toku proteklih 50 godina Kombinat aluminijuma Podgorica ubraja se među najveće potrošače električne energije u Crnoj Gori. Jedan od glavnih razloga jeste to što je proces transformacije sirovog boksita u aluminijum izuzetno intenzivan, što samim tim zahteva ogromnu količinu električne energije, vode i relevantnih izvora. S obzirom na to da je ruda čistog aluminijuma veoma čvrsta, ogromna količina električne energije je potrebna kako bi se dobio finalni proizvod i obično je više od polovine utrošene energije nastalo topljenjem uglja, koji predstavlja jedan od najvećih zagađivača poznatih čovečanstvu. S obzirom na to da je uticaj ovog kombinata na životnu sredinu ogroman, dovodi se u pitanje njegov opstanak kako sa finansijske tako i sa ekološke tačke gledišta.
\end{abstract}

Ključne reči:

emisije sa efektom staklene bašte, računovodstvo,

životna sredina, kombinat aluminijuma, energija. 